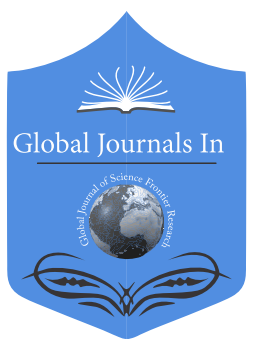

Global Journal of SCIENCE Frontier ReSEARCH: C

BIOLOGICAL SCIENCE

Volume 20 Issue 5 Version 1.0 Year 2020

Type: Double Blind Peer Reviewed International Research Journal

Publisher: Global Journals

Online ISSN: 2249-4626 \& Print ISSN: 0975-5896

\title{
Area Preference of GPS Tagged Re-Introduced Tigresses within their 100\% MCPs in Sariska Tiger Reserve, India
}

\author{
By Gobind Sagar Bhardwaj, AJT Johnsingh, Gogul Selvi, Saket Agasti, \\ Balaji Kari, Hemant Singh, Anand Kumar \& GV Reddy
}

Abstract- Area preference of three GPS tagged re-introduced tigresses (viz. ST3, ST9 and ST10) within their home ranges (MCP100\%) was done in Sariska tiger reserve (STR). The exercise was based on their point locations using GIS technology for the period of 2018-19. The observed percentage of period spent in dense forest area (ST3 $=91 \%, \mathrm{ST} 9=72.2 \%$ \& ST10 $=93.2 \%$ ) shows the preference for the dense forest as compared to the degraded forest and human settlement areas or agriculture fields within the STR. The present study further demonstrates the role of terrain, especially deep valleys/gorges and availability of perennial water sources as factors responsible for area preference by tigresses. Identification of such spots preferred by tigers in the reserve, their mapping and according maximum protection from anthropogenic interferences is recommended.

Keywords: home range, area preference, tiger reserve, water holes, sweet spots.

GJSFR-C Classification: FOR Code: $279999 p$

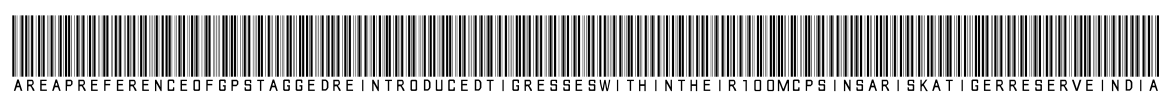

Strictly as per the compliance and regulations of:

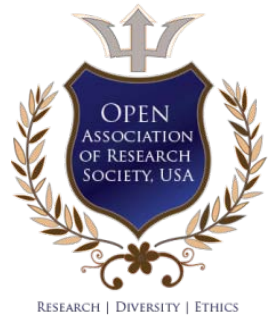

(C) 2020. Gobind Sagar Bhardwaj, AJT Johnsingh, Gogul Selvi, Saket Agasti, Balaji Kari, Hemant Singh, Anand Kumar \& GV Reddy. This is a research/review paper, distributed under the terms of the Creative Commons Attribution-Noncommercial 3.0 Unported License http://creativecommons.org/licenses/by-nc/3.0/), permitting all non commercial use, distribution, and reproduction in any medium, provided the original work is properly cited. 


\title{
Area Preference of GPS Tagged Re-Introduced Tigresses within their 100\% MCPs in Sariska Tiger Reserve, India
}

\author{
Gobind Sagar Bhardwaj ${ }^{\alpha}$, AJT Johnsingh $^{\sigma}$, Gogul Selvi ${ }^{\rho}$, Saket Agasti ${ }^{\omega}$, Balaji Kari ${ }^{*}$, Hemant Singh ${ }^{\S}$, \\ Anand $\operatorname{Kumar}^{\mathrm{X}}$ \& GV Reddy ${ }^{\mathrm{V}}$
}

\begin{abstract}
Area preference of three GPS tagged re-introduced tigresses (viz. ST3, ST9 and ST10) within their home ranges (MCP100\%) was done in Sariska tiger reserve (STR). The exercise was based on their point locations using GIS technology for the period of 2018-19. The observed percentage of period spent in dense forest area (ST3 $=91 \%$, $\mathrm{ST} 9=72.2 \%$ \& ST10 $=93.2 \%$ ) shows the preference for the dense forest as compared to the degraded forest and human settlement areas or agriculture fields within the STR. The present study further demonstrates the role of terrain, especially deep valleys/gorges and availability of perennial water sources as factors responsible for area preference by tigresses. Identification of such spots preferred by tigers in the reserve, their mapping and according maximum protection from anthropogenic interferences is recommended.
\end{abstract}

Keywords: home range, area preference, tiger reserve, water holes, sweet spots.

\section{INTRODUCTION}

$\mathrm{H}$ ome range is an area where animal spends most of its time. It is normally traversed by an individual animal or group of animals during activities associated with feeding, resting, reproduction, shelter seeking and other factors important to an animal's survival (Burt 1943, Harestad \& Bunnell 1979; Sanderson 1966). The size of a home range relates to body size (McNab 1963, Harestad \& Bunnell 1979). Large mammals have larger home ranges than smaller ones, and carnivores generally have large home ranges than herbivores and omnivores of similar size. It has been argued that solitary female felids should maintain home ranges just large enough to contain enough prey to meet their energetic demands of reproduction, with exclusive home ranges expected only when resources are distributed evenly both spatially and temporally (Sandell 1989). Many studies have documented male

Author a: Additional Principal Chief Conservator of Forests, Aranya Bhawan, Jaipur.e-mail: gobindsagarbhardwaj@gmail.com Author o: Former Scientist, Wildlife Institute of India, Dehradun, India. e-mail: ajt.johnsingh@gmail.com

Author p: Research Associate, Sariska Tiger Reserve, Alwar, India. Author w: Social Scientist, Sariska Tiger Reserve, Alwar, India. Author ¥: Deputy Consenvator of Forests, Mt Abu, Rajasthan, India. Author §: Deputy Conservator of Forests, Jhalawar, Rajasthan, India. Author x: Assistant Conservator of Forests, Nagour, Rajasthan, India. Author v: Principal Chief Conservator of Forest, Rajasthan, India. felid home-range sizes much larger than expected based on energetic demands, suggesting that other factors such as maximizing breeding opportunities influence male home-range size and degree of exclusivity (Sandell 1989). Further, studies also demonstrated that, male spatial organization of tigers is because of area occupancy pattern by female tigers (Sandell 1989, MacDonald 1983). The larger home ranges of females of Amur tiger Panthera tigris altaica is associated with lack of sufficient prey and poor habitat quality (Goodrich et al. 2005, Goodrich et al. 2010, Miquelle et al. 1999) whereas in Indian sub-continent relatively small size of adult female home range is attributed to the spatially homogenous and high abundance of prey species (Sunquist 1981, Smith et al. 1987a, Smith 1993).

Tiger (Panthera tigris L.) is the largest of all felids and is considered as the most charismatic species in the field of wildlife conservation. It is found in diverse habitat types and shows remarkable tolerance to the variation in altitude, temperature and rainfall regimes (Sunquist et al. 1999). For the last few decades tiger has drawn attention from wildlife managers, biologists and conservationists. It occupies the top position in the food chain of the forest ecosystem. Therefore it occupies a prominent position in decision making of wildlife management across the globe, especially in tiger range countries. Decision- makers and managers often view the tiger number as the measure for the performance indicator of the managerial inputs in any landscape. However, many other indicators are often neglected due to tiger centric approach adopted by the stakeholders, especially in India, which is having the largest population of wild tigers across the globe.

Following the total extinction of tigers in Sariska tiger reserve (hereafter called STR) in 2004, reintroduction of tigers was done from Ranthambhore by translocating an initial population of five tigers (two males and three females), with a supplementation of two tigers (male and female) in every three years for a period of six years (Sankar et al. 2005). A total of 9 tigers from Ranthambhore have already been translocated to Sariska using different means of transport until the study period. Three male (ST1, ST4, ST6) and three female 
tigers (ST2, ST3, ST5) were brought from Ranthambhore. In the year 2012, ST2 delivered two cubs (ST7 and ST8). Later, two female orphan cubs, ST9 and ST10, were brought from Ranthambhore in 2013. While ST10 littered two cubs (ST11 and ST12) and ST2 delivered its second litter of two cubs (ST13 and ST14) in the year 2014. One cub (ST15) was reported to be borne from ST9 in the year 2016. At the beginning of the year 2018, two cubs were borne by ST14 and three cubs ST12. Again reporting of one cub from ST10 and three cubs from ST12 at the beginning of 2020 increased the tiger number in STR. With the reported mortality of three tigers (ST1, ST11 and ST4 and one missing (ST5) (possibly killed), the current population of tigers in STR is 20 (11 adults, 5 sub-adult and 4 cubs). While debating the area requirement for different individual tigers in human-dominated landscape of STR (e.g.1213.31 km²), most of earlier studies suggested the role natural prey base (Sankar \& Johnsingh 2002; Sankar et al. 2005; Sankar et al. 2010; Sankar et al. 2013) in determining the area occupancy of tigers. However, limited numbers of studies are available demonstrating the role of terrain, dense forest and availability of perennial water sources for determining the area preference of tigers in STR. With the increasing number of tigers in reserve having 26 villages, a national highway and more than 300 religious places, the available $1213 \mathrm{~km}^{2}$ area of STR needs to be assessed. The present study was done to get answers to the following questions, (1) is there any role of dense forest in determining the area preference of tigers? (2) Is there any role of terrain and perennial water bodies in determining the area preference of tigers?

Three those were re-introduced tigresses from Ranthambhore, viz. ST9, ST10 and ST3 tigresses were collared with GPS Plus X transmitters on May 13, 2018; Nov16, 2018; and Nov 26, 2018. The ST3 was relocated from Ranthambhore in 2009 and the two orphan sibling females, ST9 and ST10, were relocated in 2013. The present study is based on the point locations as received from the satellite transmitters fitted in their collar and we attempted to answer the questions as cited above.

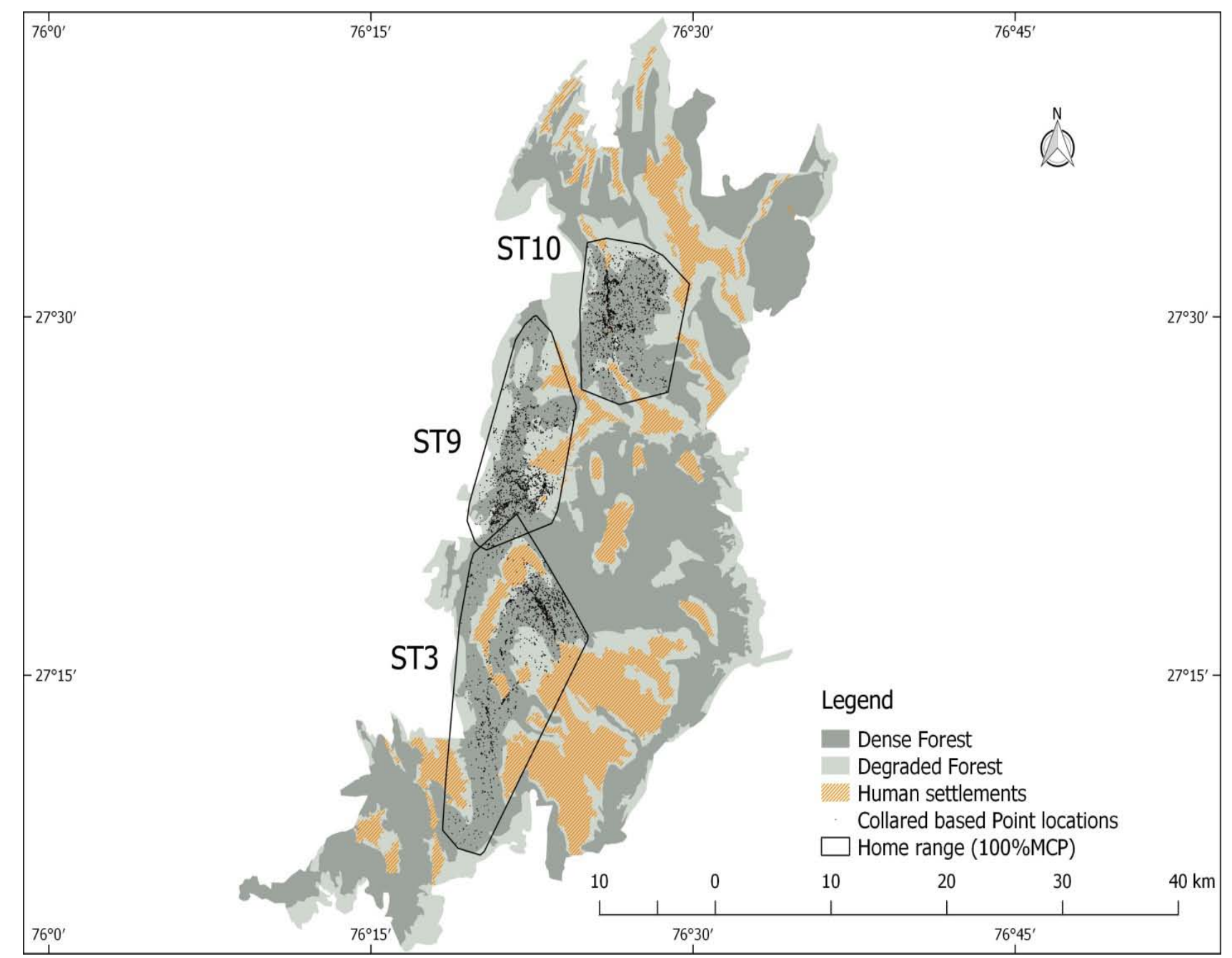

Fig. 1: Sariska Tiger Reserve showing area occupancies (MCP 100\%) of ST3, ST9 and ST10 tigresses 


\section{Materials and Methods Area}

The study area, the STR is situated in the Aravalli hill range and lies in the semi-arid part of Rajasthan (Rodgers and Panwar, 1988). The terrain is undulating to hilly and has numerous large to narrow valleys, two large plateaus-Kiraska and Kankwari and three large lakes, Silised, Mansarovar and Somasagar. The altitude of Sariska ranges from 240 to $777 \mathrm{~m}$.

It is located in the Alwar district of the state of Rajasthan. After expansion its area was increased from 881 square kilometers to 1213.31 square kilometers due to the addition of buffer area (Fig 1) with some part of buffer (Jamwa Ramgarh Sanctuary) in the district of Jaipur. The vegetation of STR is tropical dry deciduous forests (Champion and Seth, 1968). The forest being scattered and sparse over a large area on various geological and soil formation and vary greatly in composition. Anogeissus pendula is dominant species in the undulating area and on the hills. Boswellia serrata and Lannea coromandelica grow on steep rocky areas. Acacia catechu, Butea monosperma and Zizyphus mauritiana are distributed in valleys. Dendrocalamus strictus is extremely limited in distribution and is present along the well-drained reaches of the streams and moist and colder part of the hills. Among bushes, Grewia flavescence and Capparis sepiaria form important components of understorey vegetation of the reserve. Apart from the tiger (Panthera tigris L.), other carnivores present in STR include common leopard (Panthera pardus), striped hyaena (Hyaena hyaena), jackal (Canis aureus), jungle cat (Felis chaus), common mongoose (Herpestes edwardsi), small Indian mongoose $(H$. auropunctatus), ruddy mongoose (H. smithi), palm civet (Paradoxurus hermaphroditus), small Indian civet (Viverricula indica) and ratel (Mellivora camensis). Till two decades caracal (Caracal caracal) were found in this reserve. Chital (Axis axis), sambar (Rusa unicolor), nilgai (Boselaphus tragocamelus) and wild pig (Sus scrofa) are the natural prey species for tigers found in STR. Other wild prey species found are Common langur (Semnopethicus entellus), Rhesus macaque (Macaca mulatta), Indian porcupine (Hystrix indica), rufous-tailed hare (Lepus nigricollis ruficaudatus), and Indian peafowl (Pavo cristatus). About 175 villages are situated in \& around STR. Out of these, 29 (now 26 after relocation of three villages) are in Critical Tiger Habitat (CTH) and the rest 146 are outside the forest area. About 2254 families live in the core area, while about 12000 families live around the CTH (Shekhawat 2015), thus making this reserves a human-dominated landscape with immense anthropogenic pressures. Fig. 1 shows STR with a number of human habitations inside.

\section{MeTHODS}

All of the tigers that were shifted from Ranthambhore were radio-collared. Tigers were immobilized with the mixture of Xylazine and Ketamine (500 mg + $400 \mathrm{mg}$, HBM) was used as 3.2-3.5 ml. A $250 \mathrm{~kg}$ container (length $5^{\prime} 11^{\prime \prime}$, breadth $3^{\prime} 6.5^{\prime \prime}$ and height $3^{\prime} 10^{\prime \prime}$ ) was fabricated with non-slip wooden planks on the bottom and angle iron frames on sides and top for the transport of the animals (Sankar et al. 2010). Following the malfunctioning of collars of ST9, ST10 and ST3, these were replaced with Vertex plus VHF/GPS collar, VECTRONIC Aerospace Gmb using iridium satellite communication on May 13, 2018; Nov16, 2018; and Nov 26, 2018 respectively. Different GPSs of the collars for three tigresses were configured for different periods; accordingly, different number of coordinate locations was received for different tigresses. The time period for point locations were from May 13, 2018 to Nov 23, 2019 (ST9), Nov 16, 2018 to March 31, 2020 (ST10), Nov 26, 2018 to March 30, 2020 (ST3). The keyhole markup language $(\mathrm{kml})$ file of these point locations was converted into shape files using open source GIS software (QGIS 2.18.19) and analysis was done with the help of software and MS Excel. The Minimum Convex Polygon (MCP) technique was used for home-range calculation (Mohr 1947, Anderson 1982 \& Southwood 1996) and also for interpretation and comparison of home-range sizes. The use of MCPs was justified because of the sample size in the one-year study period and the temporally clustered nature of fixes that resulted in the autocorrelation of results (Swihart and Slade 1985). We estimated the age of each tiger based on their re-introduction record, known birth dates of young belonging to radio-collared mothers, evidence of having reproduced, and breeding behaviors noted after capture. The shape files for dense forests, degraded forests and agriculture settlements were generated using latest imageries from Google Earth viewed at 12675 feet. Spatial analysis was done using counts points in polygon in geometric and analysis tools of the vector using QGIS. The data for perennial source of water including the name of the water source, name of the beat, GPS coordinates, the status of water (present or absent) was collected monthly by the frontline staff for all beats from March 2018 to June 2019. The same data was sent to Field Director Office and consolidation was done in MS Excel.

\section{Observations}

We obtained 2820, 2541 and 3613 point locations for tigresses ST3, ST9 and ST10 respectively for the period, as shown in table 1. The home ranges (100\% MCP) computed for the period varies from 97.97 $\mathrm{km}^{2}$ (ST10) to 189.82 (ST3). It was observed, as 104.98 $\mathrm{km}^{2}$ for ST9. Fig 1 shows the home ranges three tigresses as shown as MCP (100\%) in STR. These home ranges were observed to be considerably higher than other tigresses (eg.ST2, ST7, ST8) of STR during the period of study owing to the phylopatry behavior of 
tigresses as ST7 and ST8 were borne to ST2. While demonstrating the percentage of time spent by tigresses in different habitats, we divided the habitat into three categories, viz. dense forest, degraded forest and human settlements/agriculture. The satellite received point locations of all tigresses were segregated from their respective 100\% MCP home range using layer intersection and $X Y$ tools of Vector of QGIS 2.18.19. The proportional representation of point locations of tigresses in these three layers was taken as proportional time spent in these habitats. Maximum time was spent in dense forest (ST3=91\%, ST9 $=72.2 \% \&$ ST10 $=93.2 \%$ ) followed by degraded forest (ST3 $=6.8 \%$, ST9 $=27.6 \% \&$ ST10 $=93.2 \%$ ) and least was used with intensive anthropogenic activities (human habitations and agriculture) (ST3 $=1.6 \%, \mathrm{ST} 9=0.2 \% \& \mathrm{ST} 10=0.5 \%)$. The computed area of different landscapes inside the individual home range (100\% MCP polygons) is shown in table 1. Detailed observations for individual tigresses are described separately to understand the natural resource selection in relation to area preference.

Table 1

\begin{tabular}{|c|c|c|c|}
\hline & ST3 & ST9 & ST10 \\
\hline Year of relocation & 2009 & 2013 & 2013 \\
\hline Age of tigress in years & 14 & 10 & 10 \\
\hline $\begin{array}{l}\text { Date of putting GPS collar (year } \\
\text { 2018) }\end{array}$ & $23 \mathrm{Nov}$ & 13 May & $16 \mathrm{Nov}$ \\
\hline $\begin{array}{l}\text { Period of data in number of } \\
\text { days }\end{array}$ & 492 & 559 & 502 \\
\hline Point locations for tigresses & 2820 & 2541 & 3613 \\
\hline Point locations in dense forest & 2585 & 1835 & 3369 \\
\hline $\begin{array}{l}\text { Point Location in degraded } \\
\text { forest }\end{array}$ & 191 & 702 & 225 \\
\hline $\begin{array}{l}\text { Point location in human } \\
\text { habitations and agriculture }\end{array}$ & 44 & 4 & 19 \\
\hline $\begin{array}{l}\text { Home range of individual } \\
\text { tigress } \mathrm{MCP}(100 \%) \text { in } \mathrm{Km}^{2}\end{array}$ & 189.82 & 104.98 & 97.97 \\
\hline $\begin{array}{l}\text { Dense forest in inside home } \\
\text { range } \mathrm{MCP}(100 \%) \text { in } \mathrm{Km}^{2}\end{array}$ & 109.9 & 56.13 & 68.01 \\
\hline $\begin{array}{l}\text { Degraded forest inside home } \\
\text { range } \mathrm{MCP}(100 \%) \text { in } \mathrm{Km}^{2}\end{array}$ & 79.92 & 48.85 & 29.96 \\
\hline $\begin{array}{l}\text { Percent of dense forest in } \\
\text { home range in } \mathrm{Km}^{2}\end{array}$ & 57.9 & 53.5 & 69.4 \\
\hline
\end{tabular}

Tigress ST3

One of the siblings of three female cubs of fourth litter from T16 tigress of Ranthambhore born in 2006 was relocated to STR in 2009 as a part of the reintroduction of tigers. Her predecessor tigress ST2 had already occupied Sariska-Kachida valley, an important area or sweet spot of STR with plenty of prey base. While occupying southern portion of STR, $70.37 \%$ of her reported kills (based on individual tiger monitoring) were those of livestock, including buffaloes and cows between 2016 to 2018 (Bhardwaj et al. 2020). Although the percent of dense forest inside the home range of ST3 was $57.9 \%$, the tigress was observed to spent $91 \%$ of her time in dense cover while rest of the time in degraded areas, including human-dominated landscapes. While attempting to demonstrate the temporal segregation of time period in degraded forests and human habitations including agriculture fields, ST3 was observed wandering mostly during night hours (viz.
$62.30 \%$ in degraded areas and $69.91 \%$ in humandominated landscapes) among the total observations. 


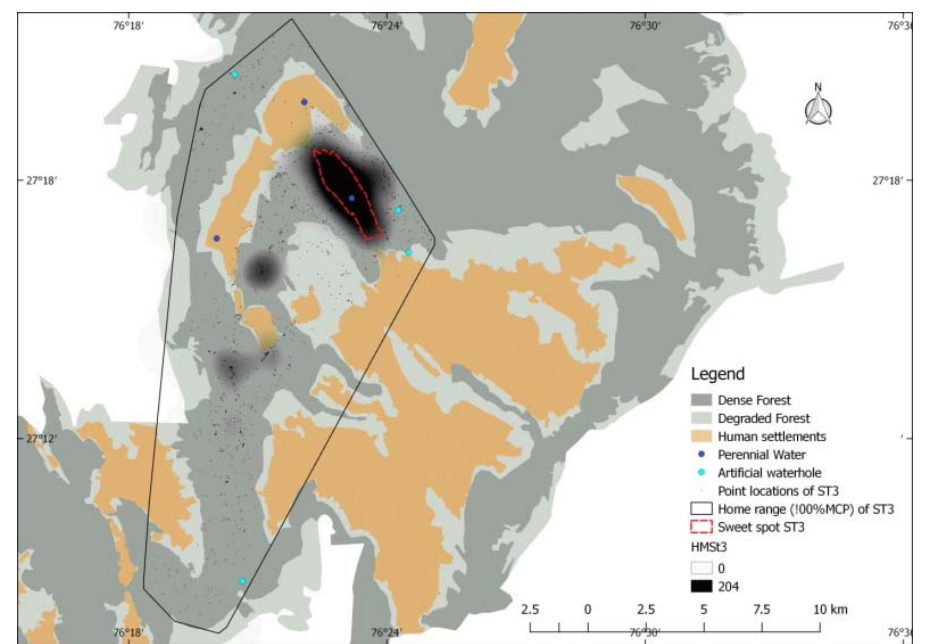

Fig. 2: Home range (MCP100\%) of ST3 tigress showing with heat map, sweet spot, and water points in different forest types. Whereas AWHs is artificial water holes and NWS is natural water source

Based on the data analysis of the water tracking report from March 2018 to June 2019, sixty natural perennial water holes were identified in STR. These perennial sources were observed to have water for the whole of the year. The perennial water sources falling in home range of tigress ST3 along with different landscapes in the MCP100\% polygons are shown in figure 2 .

Among all natural water source (NWS) as shown in the polygon, only one water point is in dense forest and the rest of the points (NWSs) are located in human dominated landscapes including habitations and agriculture fields.

Tigress ST9

ST9, with an approximate age of 10 years, is one of the two orphan cubs (another sibling is ST10) those were translocated from Ranthambhore tiger reserve in the year 2013. She reportedly gave birth to one male cub, ST15 in, 2015, who has established its territory in the southern portion of STR. Based on point locations ( $n=2541$ of all 559 days), the observed home range (MCP100\%) of ST9 is $104.98 \mathrm{~km}^{2}$. Almost half of the area $(56.13 \%)$ of its home range is having dense forest where it was observed to spend the third quarter of her time $(72.2 \%)$ and rest in the degraded forest $(27.6 \%)$ and human-dominated landscapes (0.2\%). While comparing with ST3 tigress, it was observed that comparatively considerable period was spent in degraded areas of its polygon by ST9.

The tigress was observed visiting equally during the day (52\%) and night hours (48\%) in degraded areas.

Five perennial water points were observed to be located in the southern half portion of the home range (MCP100\%) of ST9. Even the artificial waterholes which were being filled for the whole of the year also occupy the southern half of the home range polygon. The observation of location congregations of tigress ST9 in the southern half of occupancy polygon suggests affinity of the tigress to the proximity of water holes, especially perennial sources.

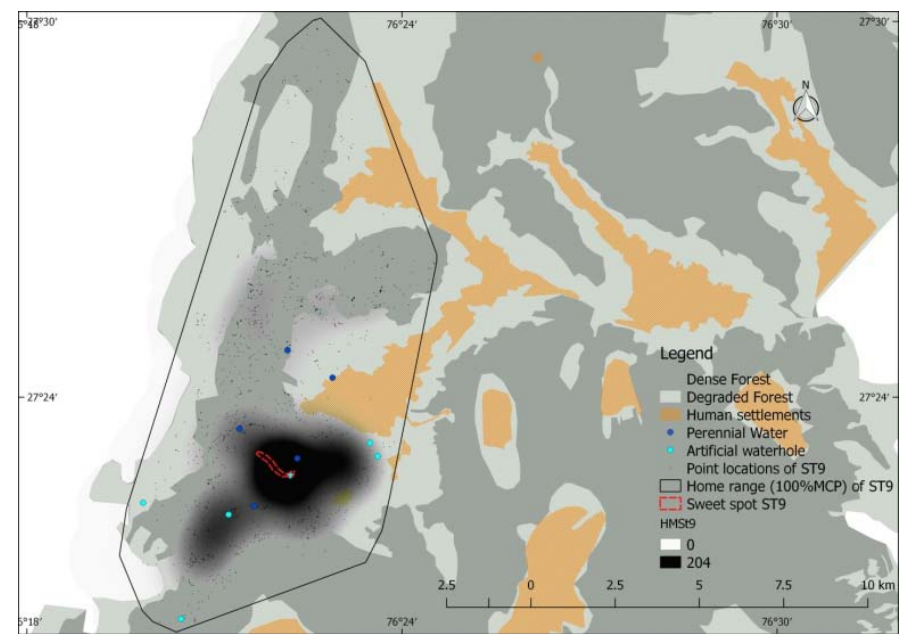

Fig. 3: Home range (MCP100\%) of ST9 tigress showing with heat map, sweet spot, and water points in different forest types. Whereas AWHs is artificial water holes and NWS is natural water source 


\section{Tigress ST10}

ST10, with an approximate age of 10 years, a sibling of ST9, that was translocated from Ranthambhore tiger reserve in the year 2013. The computed area of the home range (MCP100\%) for ST10 was observed as $98 \mathrm{~km}^{2}$, which is almost half of the ST3 tigress. Two-third of its area (69.4\%) in the home range of ST10 is of dense forest and the rest $(30.6 \%)$ is either the degraded area or with human-dominated landscapes with human habitations and agriculture. Among all received point locations $(n=3613)$ for ST10 tigress, 93.2\% were observed in the dense forest, although the proportion of rest of the degraded and human-dominated landscape was roughly one-third (30.6\%).

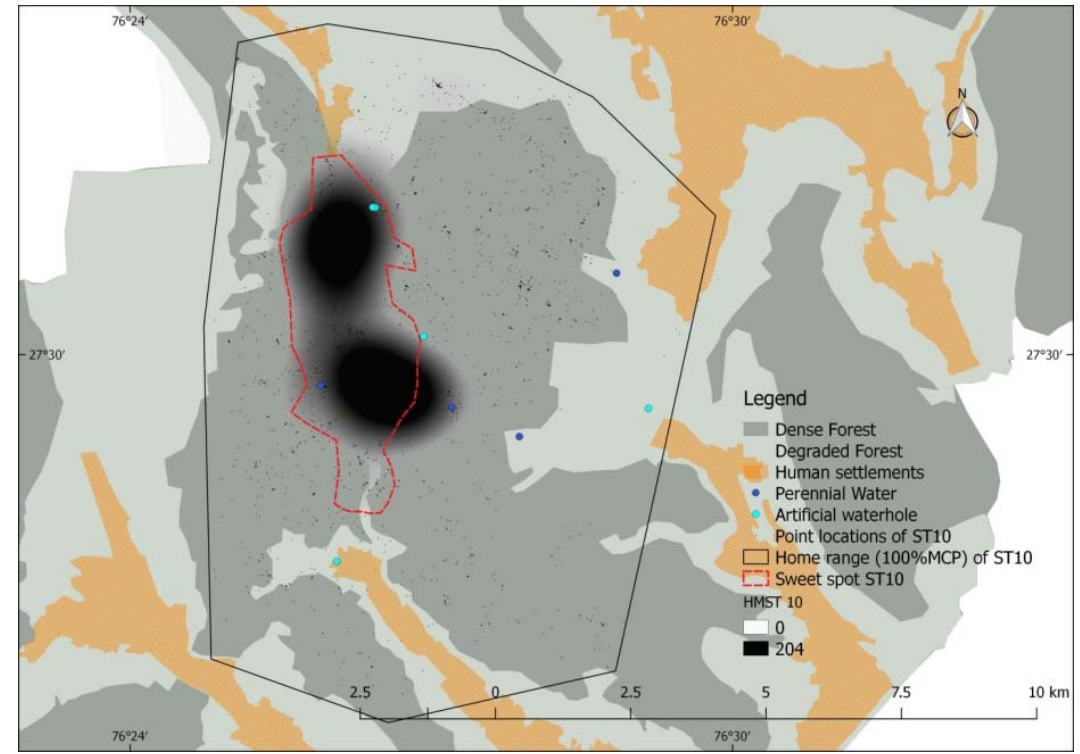

Fig. 4: Home range (MCP100\%) of ST10 tigress showing with heat map, sweet spot, and water points in different forest types. Whereas AWHs is artificial water holes and NWS is natural water source

Four perennial water sources with a permanent source of water for the whole of the year are located in the home range of ST10. Among these, two are located in the center of the polygon in dense forest where the congregation of point location of ST10 tigress was observed maximum and two water points in degraded forest area showing less congregation (fig 4).

While attempting to map the sweet spots of all these three tigresses in their respective home ranges, maximum preference was given by individual tigresses in the valleys and gorge areas. Fig 2, 3 and 4 show the heat maps generated from point location spatial data using QGIS. An area of $4.13 \mathrm{~km}^{2}$ locally called Baghani was observed to be intensively used by tigress ST3 with 683 point locations, which are approximately 11 times more than those in MCP100\% for total home range. While analyzing the terrain of this polygon, it was observed to be a narrow valley with perennial water source in the area. Similarly, the observation of maximum utilization of valley by ST9 tigress with 243 point locations in just $0.17 \mathrm{~km}^{2}$ which is approximate 59 times more than rest of the area of polygon, demonstrates the tigress's preference for the valley. The computed maximum congregation of point locations $(n=248)$ of tigress ST10 in just $10.9 \mathrm{~km}^{2}$ is again a valley area) with thick vegetation dominated by Butea monosperma species.

\section{Discussion}

Earlier Sunquist (1981) demonstrated that both felids, tiger and leopard, are territorial and wide-ranging. Still the effective size of the territory is the function of density and biomass of larger prey species in their habitat. In STR too, past studies highlighting the role of natural prey base in determining the area occupancy of wild tigers have already been demonstrated in tiger range countries (Sankar \& Johnsingh 2002; Sankar et al. 2005; Sankar et al. 2010; Sankar et al. 2013). Above studies demonstrate the role of natural prey base in determining the area occupancy of tigers. In humandominated landscapes where the proportion of natural prey base is far below than livestock available in proximity to a predator as evident from a study done in the same landscape (Bhardwaj et al. 2020), the role of other factors like human disturbance, natural cover, availability of water or terrain of the area can be viewed as determining factors for area preference for tigers. Based on reported kills by tigers in STR (between 2016 and 2018), the observation of a maximum number of kills of livestock (77\%) followed by Sambar Rusa unicolor (13.6\%), chital Axis axis (3.6\%), blue bull Boselaphus tragocamelus (2.4\%) and wild pig Sus scrofa (0.95\%) demonstrates the less dependence on natural prey base in determining the area preference 
tigers (Bhardwaj et al. 2020). When the number of unaccompanied livestock in an area is more than wild prey, naturally, tigers will go for livestock. Apart from the role of prey, here we attempted to highlight the significance of dense forest (cover), terrain and perennial water sources in area preference of tigers within their home ranges. Almost all of the three tigresses showed the preferences for the dense forest with the maximum percentage by ST3 (91\% of all point locations for $58 \%$ dense forest within MCP $100 \%$ of ST3) and ST10 (93.2\% of all point locations for $69.4 \%$ dense forest within MCP100\% of ST10). Although ST9 also preferred for the dense forest but relatively less $(72.2 \%$ of all point locations for $53.5 \%$ dense forest within MCP $100 \%$ of ST9) as compared to ST3 and ST10. It can be explained by the presence of several perennial water holes as well as artificial waterholes in the degraded area too especially in southern portion of the home range of the tigress. These waterholes also explain the skewed distribution of location points of ST9 in the lower half of her home range.

Spending most of the time in dense forest $(91 \%$ point locations), the biggest congregation of point locations of ST3 was observed to be located in the north-portion of its home range (Fig 2). The reason for this high congregation can be attributed to the presence of a perennial natural source (no.1). Although there are three other perennial natural sources (NWS) however these are located in degraded areas and near human habitations, thus tigress avoiding these locations. Similarly, the observation of the largest congregation of point locations near two perennial water sources in dense forest within the home range of ST10 tigress shows its preference for perennial water sources in the dense forest only. Largest congregations of point locations of all these tigresses in valleys also demonstrate the importance of terrain, especially deep gorges and valleys as area preference by mega carnivores. Thus, valleys with dense vegetation and availability of perennial water sources throughout the year in the semi-arid landscape of Aravallis are the determining factors for area preference for tigers when natural prey base is not only a limiting factor. The skewed location of natural perennial water holes in home ranges of individual tigresses further invites the managerial interventions for selecting sites for artificial water holes in a continuous pattern inside the home range polygons. The preference of tigresses for dense forest again highlights the urgent need to protect the degraded forest areas of the STR from anthropogenic pressures to enhance the vegetative cover. This can be done only through the voluntary relocation of villages from critical tiger habitat and strengthening of enforcement regime of Sariska administration through immediate filling up of the vacant posts of forest guards, creation of Sariska Tiger Protection Force (STPF) and reviewing the strength and number of existing frontline staff (Bhardwaj 2018). As the tiger number is increasing through strict tiger monitoring in reserve, we also recommend that such sweet spots to be identified for all tigresses and necessary managerial efforts are to be made to make these areas as totally free from any anthropogenic activities. While the process of voluntary relocation of villages from STR is certainly going to take some time, the protection of at least these high congregation areas called sweet spots of the tiger will act as escape refuge for these tigers in the humandominated tiger reserve.

\section{ACKNOWLEDEMENT}

We thank Rajasthan Forest Department, frontline staff, monitoring parties for helping this study. We also thank Dr. PK Malik, Dr. Parag Nigam, Dr. Bilal Habib, all scientists from Wildlife Institute of India for their help and guidance. We express sincere thanks to Dr. Arvind Mathur Veterinary officer, Jaipur Zoo for immobilizing the tigresses as per authorized protocol.

\section{References Références Referencias}

1. Anderson, J.1982. The home range. A new non parametric estimation technique. Ecology, 63: 103-112.

2. Bhardwaj, G.S. 2018. Sariska Tiger Reserve: A managerial approach to the problems of landscape. Indian Forester, 144 (10): 900-910, 2018.

3. Bhardwaj, G. S., Selvi, G., Agasti, S., Kari, B., Singh, H., Kumar, A., Reddy, G.V. 2020. Study on kill pattern of re-introduced tigers, demonstrating increased livestock preference in human dominated Sariska tiger reserve, India, SCIREA Journal of Biology. Vol. 5 , No. pp. 20 - 39.

4. Burt, W. H.1943. Territoriality and home range concepts as applied to mammals. J. of Mammal, 24:346-352

5. Champion, H.G., Seth, S.K. 1968. A revised survey of the forest type of India. Government of India Press, Delhi, pp. 404.

6. Goodrich, J.M., Kerley, L.L., Miquelle, D.G., Smirnov, E.N., Quigley, H.B. \& Hornocker, M.G. 2005. Social structure of Amur tigers on Sikhote-Alin Biosphere Zapovednik. In: Miquelle, D.G., Smirnov, E.N. \& Goodrich, J.M. (eds). Tigers of Sikhote-Alin Zapovednik: Ecology and Conservation, PSP, Vladivostok, Russia (in Russian), pp. 50-60.

7. Goodrich, J.M., Miquelle, D.G., Smirnov, E.N., Kerley, L.L., Quigley, H.B. \& Hornocker, M.G. 2010. Spatial structure of Amur (Siberian) tigers (Panthera tigris altaica) on Sikhote-Alin Biosphere Zapovednik, Russia, J. of Mamm., 91(3):737-748.

8. Harestad, A. S. \& Bunnell, F. L. 1979. Home range and body weight - a reevaluation. Ecology, 60: 389-402. 
9. Karanth, K.U. 1999. Ecology and management of tigers in tropical Asia. In: Maruyama, Bobek, B., Ono, Y., Regelin, W., Bartos, L., and Ratcliffe, R. (Ed.), Wildlife conservation: Present trends and perspectives for the 21st century. Japan wildlife research center, Tokyo, 156-159.

10. Macdonald, D.W. 1983. The ecology of carnivore social behaviour. Nature, 301: 379-384.

11. McNab, B.K. 1983. Bioenergetics and the determination of home range size. Am. Nat., 97: 133-40.

12. Miquelle, D.G., Smirnov, E.N., Merrill, W.T., Myslenkov, A.E., Quigley, H.B., Hornocker, M.G. \& Schleyer, B. A habitat protection plan for the Amur tiger. 1999. In: Riding the tiger: meeting the needs of people and wildlife in Asia. Seidensticker, J., Christie, S. \& Jackson, P (Eds). Cambridge: Cambridge University Press, pp. 273- 295.

13. Mohr, C.O.1947. Table of equivalent populations of North American small mammals. American Midland Naturalist, 37:223-249.

14. Rodgers, W.A., Panwar, H.S. 1988. Planing a wildlife protected area network in India Vol. I \& II Wildlife Institute of Dehradun.

15. Sandell, M. 1989. The mating tactics and spacing patterns of solitary carnivores. In: Gittleman, J. L. (Ed.). Carnivore behavior, ecology and evolution. Cornell University Press, Ithaca, New York, pp. 164-182.

16. Sanderson, G. C. 1966. The study of mammal movements - a review. Journal of Wildlife Management, 1966, 52:316- 320.

17. Sankar, K. and Johnsingh, A.J.T. 2002. Food habits of tiger (Panthera tigris) and leopard (P. pardus) in Sariska Tiger Reserve, Rajasthan, India, as shown by scat analysis. Mammalia, 66(2):285-289.

18. Sankar, K., Goyal, S.P. and Qureshi, Q. 2005. Assessment of status of tiger in Sariska Tiger Reserve Rajasthan. A Report submitted to the Project Tiger, Ministry of Environment and Forests, Government of India, New Delhi.

19. Sankar, K., Qureshi, Q., Mondal, K., Worah, D., Srivastava, T., Gupta, S. and Basu, S., 2009. Ecological studies in Sariska Tiger Reserve, Rajasthan. Final Report. Wildlife Institute of India, Dehra Dun, p. 145.

20. Sankar, K., Qureshi, Q., Nigam, P., Malik, PK., Sinha, PR., Mehrotra, RN., Gopal, R., Bhattacharjee, S., Mondal, K. and S. Gupta. 2010. Monitoring of reintroduced tigers in Sariska Tiger Reserve, Western India: Preliminary findings on home range, prey selection and food habits. J. Trop. Conserv. Sci., 3(3): 301-318.

21. Sankar. K., Nigam. P., Malik, P.K., Qureshi Q. and Bhattacharjee, S. 2013. Monitoring of Reintroduced Tigers (Panthera tigris tigris) in Sariska Tiger Reserve, Rajasthan. Technical report-1. July 2008-
March 2013. Wildlife Institute of India, Dehradun, pp 141.

22. Shekhawat, R.S. 2015. Tiger Conservation Plan of Sariska Tiger Reserve, Jaipur.

23. Smith, J.L.D., McDougal, C. \& Sunquist, M.E. Female land tenure system in tigers. 1987a. In: Tilson, R.L. \& Seal, U.S. (Eds). Tigers of the world: the biology, biopolitics, management and conservation of an endangered species. Noyes Publications, Park Ridge, New Jersey, USA, pp. 97-109.

24. Smith, J.L.D. 1993. The role of dispersal in structuring the Chitwan tiger population. Behaviour, 124: 165-195.

25. Southwood, T.R.E. 1996. Ecological methods. Methuen, London, U.K.

26. Sunquist, M. E. 1981. The social organization of tigers (Panthera tigris) in Royal Chitwan National Park. Smithsonian Contributions to Zoology, 336: 1-98.

27. Sunquist, M.E, Karanth, U.K. and Sunquist, F. 1999. Ecology, behavior, and resilience of the tiger and its conservation needs. In: Riding the tiger: tiger conservation in human dominated landscapes (J. Seidensticker, S. Christie, and P. Jackson, eds.). Cambridge University Press, Cambridge, United Kingdom, Pp. 5-18.

28. Swihart, R. K. and Slade, N.A. 1985. Influence of sampling interval on estimates of home-range size. Journal of Wildlife Management, 49:1019-1025. 